\title{
Levels of PCDDs and PCDFs in the Bleached Pulp from Chinese Pulp and Paper industry
}

\author{
M.-H. Zheng, Z-C. Bao, K.-O. Wang, X.-B. Xu \\ Research Center for Eco-Environmental Sciences, Chinese Academy of Sciences, P. 0. \\ Box 2871, Beijing 100085, People's Republic of China
}

Received: 21 January 1997/Accepted: 5 March 1997

Trace of polychlorinated dibenzo-p-dioxins (PCDDs) and polychlorinated dibenzofurans (PCDFs) are generated as by-products during the bleaching of pulp with chlorine(Rappe et al. 1989; Swanson et al. 1988; Voss et al: 1988). In the last years, some very detail studies in the field of pulp bleaching are carried out(Dimmel et al. 1993; Hrutfiord et al. 1992; Luthe et al. 1994; Luthe 1996; Santl et al.1994), but the investigations were made only in these mills which use wood or recycled wastepaper for fiber. There is still no report on the levels of PCDDs and PCDFs in pulps that use non-wood plant fibers as raw materials. However, non-wood plant fibers in paper makng today in China are dominant. Cereal and rice straws together with reeds account for $60 \%$ of raw materials in Chinese pulp and paper industry(Yu 1993). Bleaching of non-wood plant fibers in China usually requires only a single step of hypochlorite bleaching process. In this paper we present the results of PCDDs and PCDFs levels in some bleached pulps which were taken from five paper mills in the north of China.

\section{MATERIALS AND METHODS}

Each of the five mills is an integrated bleached kraft pulp and paper mill. Raw materials are pulped using the kraft process, bleached and converted on site into different kind of paper. Bleaching sequences including the following stages: $C$ (chlorine), E(alkaline extraction), $\mathrm{H}$ (hypochlorite). Raw materials and bleaching sequences at the five mills are indicated in Table 1.

The analytical method has been published in detail(Swanson et al. 1988). Fifty grams of air-dry samples are spiked with a mixture of eight ${ }^{13} \mathrm{C}$ labelled PCDD/Fs (Cambridge Isotope Laboratories) prior to their $24 \mathrm{hr}$ 
Table 1. Description of bleached pulp samples

\begin{tabular}{|c|c|c|c|c|c|}
\hline Mill & $A$ & $B$ & $C$ & $D$ & $E$ \\
\hline Raw material & $\begin{array}{l}\text { rice } \\
\text { straw }\end{array}$ & $\begin{array}{l}\text { rice } \\
\text { straw }\end{array}$ & $\begin{array}{l}\text { cereal } \\
\text { straw }\end{array}$ & reed & $\begin{array}{l}\text { wood } \\
\text { manufactur- } \\
\text { ing residuals }\end{array}$ \\
\hline Bleaching process & $5 \mathrm{H}$ & $\mathrm{H}$ & $\mathrm{H}$ & CEH & $\mathrm{H}$ \\
\hline
\end{tabular}

The sample from Mill $\mathrm{D}$ is collected after $\mathrm{C}$-stage bleaching process.

Soxhlet extraction with toluene, following concentration by rotary evaporation. The bulk of the co-extracted organic material is removed by successively passing the extract through the following series of chromatographic columns: acid silica, acid-base silica multilayer, and basic alumina. Just prior to GC-MS analysis, two ${ }^{13} \mathrm{C}$-labelled recovery standards (Cambridge Isotope Laboratories) are added for the quantification of surrogate recovery. One sample blank is analyzed for every five samples. All analyses are carried out by VG-7070E- HF GC/MS using a $60 \mathrm{~m}$ SP-2331 (Supelco) fused-silica column. Quantification of PCDDs and PCDFs is performed in selected-ion monitoring mode. For each congener, two most abundant ions of molecular ion clusters are measured.

\section{RESULTS AND DISCUSSION}

The results of the sample analyses which are expressed in $\mathrm{pg} / \mathrm{g}$ of sample for the toxic 2378-substituted congeners and also in pg/g of TCDDequivalents using I-TEQ are given in Table 2. The mean recoveries of the samples are in the range from 110 up to $125 \%$.

The content of 2378-TCDD in the pulps from pulp and paper mills in China is higher than that of bleached hardwood and softwood pulps ever reported(Amendols et al. 1989; Kitunen et al. 1989; Rappe et al.1990; Swanson et al. 1988;). The amounts of PCDFs are significantly low compared to those of PCDDs. A typical 'bleaching pattern' of bleached kraft wood pulps is dominated by 2378-TCDD, 2378-TCDF and 1378TCDF isomers, but none of TCDF isomer is detected in the pulps in this study. The reason for this may be different genesis of these compounds.

The mechanisms of PCDDs and PCDFs formation during the bleaching of non-wood plant fiber pulps with hypochlorite are also studied. We have explored the possibility that PCDDs and PCDFs may be originated from dibenzo-p-dioxin(DBD), dibenzofuran(DBF) and chlorinated phenols(CPs). Five grams of unbleached non-wood fiber pulp are washed by diluting to $5 \%$ consistency with deionized water and injecting 0.1-1.0 ml of DBD, 
Table 2. PCDDs and PCDFs in various pulp samples (pg/g dry pulp)

\begin{tabular}{|c|c|c|c|c|c|}
\hline & $A$ & B & $\mathrm{C}$ & $\mathrm{D}$ & $E$ \\
\hline $2378-T_{4} C D D$ & 20.9 & 17.2 & 22.5 & 15.2 & 26.1 \\
\hline $12378-P_{5} C D D$ & 28.8 & 35.2 & 17.9 & 25.7 & 21.2 \\
\hline $123478-\mathrm{H}_{6} \mathrm{CDD}$ & 28.9 & 41.7 & 18.3 & 46.3 & 23.1 \\
\hline $123678-\mathrm{H}_{6} \mathrm{CDD}$ & 35.3 & ND & ND & ND & ND \\
\hline $123789-\mathrm{H}_{6} \mathrm{CDD}$ & 5.1 & 39.8 & 10.3 & 6.2 & 14.6 \\
\hline $1234678-\mathrm{H}_{7} \mathrm{CDD}$ & 24.5 & 39.8 & 10.3 & 6.2 & 14.6 \\
\hline OCDD & 53.7 & 111.9 & 68.9 & 290.9 & 40.4 \\
\hline $234678-\mathrm{H}_{6} \mathrm{CDF}$ & 13.2 & 1.2 & ND & 6.4 & ND \\
\hline $1234678-\mathrm{H}_{7} \mathrm{CDF}$ & 5.9 & 4.1 & 6.0 & 4.2 & 25.5 \\
\hline OCDF & 9.8 & 2.0 & 3.8 & 69.8 & 18.9 \\
\hline I-TEQ & 43.9 & 39.6 & 33.5 & 33.8 & 39.5 \\
\hline
\end{tabular}

ND : not detectable ( $(1.0 \mathrm{pg} / \mathrm{g})$

DBF, CPs $(100 \mu \mathrm{g} / \mathrm{ml}$ methanol) while stirring. Pulp is then bleached with hypochlorite. Tetra- through octa- congeners of PCDDs and PCDFs analyses are performed as mentioned above. A comparison of the spike data with that of control for PCDDs and PCDFs analysis, no significant differences exist between the two. Hence it may be concluded that DBD, DBF and CPs are not PCDDs and PCDFs precursors during bleaching of non-wood fiber pulps with hypochlorite.

Acknowledgments. This study was supported by National Science Foundation of China. Grant no. 29677025

\section{REFERENCES}

Amendola G, Barna D, Blosser R, LaFleur L, McBride A, Thomas F, Tiernan T, Whittemore $R(1989)$ The occurrence and fate of PCDDs and PCDFs in five bleached kraft pulp and paper mills. Chemosphere 18:1181-1188

Dimmel DR, Riggs KB, Pitts G, White J, Lucas S(1993) Formation mechanisms of polychlorinated dibenzo-p-dioxins and dibenzofurans during pulp chlorination. Environ Sci Technol 27:2553-2558

Hrutfiord BF, Negri AR( 1992) Chlorinated dibenzofurans and dibenzodioxins from lignin models. Tappi 75(9):129-134

Luthe CE, Berry RM, Voss $\mathrm{RH}(1994)$ Are chlorinated phenols precursors of bleach plant dioxins? Chemosphere 28: 1883-1894

Luthe CE(1996) Octachlorinated dioxin in pulps and effluents: Where does it come from? Chemosphere 32:2409-2425 
Kitunen VH, Salkinoja-Salonen MS(1989) Occurrence of PCDDs and PCDFs in bleaching processes from pulp and paper industries. Chemosphere 19:721-726

Rappe C, Swanson S, Glas B, Kringstad KP, De Sousa F, Johansson L, Abe,Z (1989) On the formation of PCDDs and PCDFs in the bleaching of pulp. Pulp Paper Can 90(8): 42-47

Rappe C, Glas B, Kjeller L-O, Kulp SE, de Wit C, Melin A(1990) Levels of PCDDs and PCDFs in products and effluent from the Swedish pulp and paper industry and chloralkali process. Chemosphere 20:17011706

Santl H, Gruber L, Stohrer E(1994) Some new sources of polychlorinated dibenzodioxins(PCDDs) and dibenzofurans(PCDFs) in waste papers and recycled pulps. Chemosphere 29: 1995-2003

Swanson S, Rappe C, Malmstrom J, Kringstad KP(1988) Emissions of PCDDs and PCDFs from the pulp industry. Chemosphere 17:681-691

Voss RH, Luthe CE, Fleming BI, Berry RM, Allen LH(1988) Some new insights into the origins of dioxins formed during chemical pulp bleaching. Pulp Paper Can 89(12): 151-162

Yu YJ(1993) The situation and perspective of raw materials in Chinese pulp and paper industry. Paper and Paper Making(China) 4:4-5 